\title{
The Impact of International Remittances on Education and Health in Bangladesh
}

\author{
Bezon Kumar \\ Department of Economics, Rabindra University, Bangladesh, Sirajganj, Bangladesh \\ Email address: \\ bezon.kumar3@gmail.com \\ To cite this article: \\ Bezon Kumar. The Impact of International Remittances on Education and Health in Bangladesh. International Journal of Science and \\ Qualitative Analysis. Vol. 5, No. 1, 2019, pp. 6-14. doi: 10.11648/j.ijsqa.20190501.12
}

Received: April 21, 2019; Accepted: June 4, 2019; Published: June 18, 2019

\begin{abstract}
Over last few decades international remittances are playing a vital role in the socio-economic development of the developing countries like Bangladesh. Remittance contributes not only in household level but also in community and national level of a country. Although many studies have been carried out on poverty, growth, inequality, unemployment impact of remittances, impact of international remittances on education and health in Bangladesh has not been studied yet. Therefore, this study explores the impact of international remittances on education and health in Bangladesh. In achieving the objective, the study uses primary data collected from 396 households and applies both statistical and econometric methods. Firstly, the study uses statistical approach to bring to light the core scenario of education and health conditions of the households. Secondly, the study separately applies linear regression model estimated through OLS method to examine the impact of international remittances on education and health. The study finds that international remittances have negative and significant impact on education while international remittances have positive and significant on health. This paper finds that if the households receive remittance, the per capita expenditure on health may be increased by Tk. 4817.39 and the per capita expenditure on education may be decreased by Tk. 1020.67. Therefore, the study suggests government and non-government organizations nursing international remittances to improve households' health.
\end{abstract}

Keywords: International Remittances, Education, Health, Bangladesh

\section{Introduction}

The significance of remittances to the developing economies can never be ignored. Globalization is transforming the developing countries for the emancipated flow of goods and factors of production embracing labor across boundaries. According to United Nations Department for Social and Economic Affairs (UNDESA), worldwide international migrants have mounted to 258 million in 2017 from only 172 million in 2000 and total international remittances for 2017 were stated as \$613 billion [1]. India, Bangladesh, Pakistan, and Mexico are among the top ten countries of the world enclosing the highest number of international migrants and receiving the topmost international remittances [2]. Explicitly in Bangladesh, every third household has one migrated member and thus receives foreign remittance [3]. At present, there are 7.8 million migrants from Bangladesh living and working abroad and remittances sent to households from employment abroad account for $\$ 9.3$ billion up to July 2018 [4-5]. This source of income relaxes the liquidity and budget constraints [6], enables consumption smoothing [7], and thus can improve health and education status [8]. Despite its significance, the impact of international remittances on household healthcare and educational expenditure is still an unexplored area in Bangladesh. For example, Chaaban and Mansour [9] targeted educational attendance and attainment in Jordan, Syria, and Lebanon. Phuyal, et al. [10] investigated spending pattern of foreign remittance and found that it is largely consumed on food and education. Further, Edwards and Ureta [11] investigated the link between remittances and schooling decision. On the other hand, remittance and health-related studies suggested a positive link between foreign remittances and health care expenditures in Mexico using household surveys [12-13]. According to World Bank statistics, education and health care expenditures incurred 
by the Bangladesh government display almost horizontal pattern from 2000 to 2012 . A noteworthy fact is that growth in remittance from 2000 to 2012 did not appreciate either of healthcare and educational expenditures are shown in Figure 1.

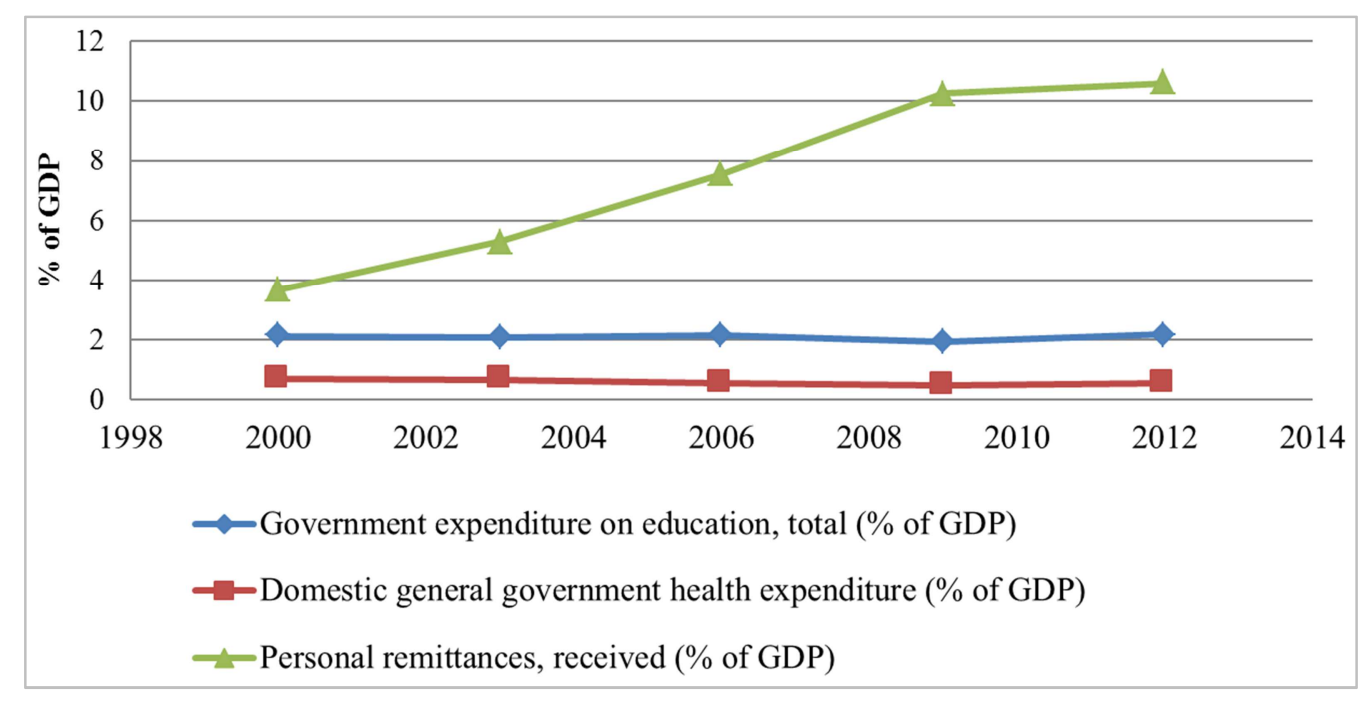

Source: World Development Indicators

Figure 1. Relationship between International Remittances and Government Expenditure on Education and Health.

Rest of this chapter is divided into four sections. The second portion has profound literature review. Methodology has been discussed in the third section and fourth part describes the data analysis. The chapter is concluded with few recommendations in last section.

\section{Literature Review}

This section describes the earlier studies' core findings on the ongoing issue. Reviewing literature, it is observed that different researchers have found different findings using different methods. As for example, Adams and Cuecuecha [14] defined remittances as money or goods transmitted by workers from the migration destination to their origin. Foreign remittances have been studied so far in terms of their contribution to the sending societies like improving consumption levels, paying back loans, getting better education, convalescing health facilities, building homes, funding an investment [15-20], or paying utility bills [19] and reducing poverty [21-22]. Positively supplementing the income level of left behinds, remittances are considered a key source to fund education and health care expenditures directly or indirectly [23].

Remittances are positively associated with education and health through removal of liquidity constraints. Lifiting up budget limitations allow households to invest more in education and health because their ability to pay unfolds. Previously, remittances-education related studies concentrated on educational performance, education attainment, and school enrollment and retention. Like Chaaban and Mansour [9] found a positive relationship between remittances and children education attendance and attainment in Syria, Jordan, and Lebanon. Phuyal, et al. [10] investigated expenditure patterns of international remittances in Kathmandu and found remittances are mostly consumed for food and education. Another study by Edwards and Ureta [11] examined the impact of remittances on household's schooling decision and discovered its significantly positive relationship with school retention in El Salvador. Moreover, spending of remittances differs from boys to girls [24-25]. It has also been observed that Mexican communities with high inflow of international remittances have larger literacy concentration [26]. Opposingly, international remittances might impact negatively the educational performance via absenteeism effect. Negative shocks in labor market of destination country may compel the left behind family members to work at the cost of education. It may distrub the family life and can deteriorate the children educational outcomes. For example, McKenzie and Rapoport [27] reported significantly negative impact of migration on educational attainment for rural Mexican children. Also, Antman [28], Lee and Park [29], and Mansoor and Quillin [30] supported similar findings.

Being a dark area for scholars, international remittances and health-focused researches mainly targeted health outcomes [31-33, 8], healthcare outlays in expenditure pattern [34-35, 10], and mortality rate [23]. For instance, Amuedo-Dorantes and Pozo [12] provided the positive connection between foreign remittances and healthcare expenditures incurred by households in Mexico. Similarly, Valero-Gil [13] stated the direct relationship between the two by employing a Tobit model. Further, they reported interesting results that remittances are less devoted to healthcare expenditure in lower income households. Differences in health expenditure are asserted to be dependent upon remittance amount received by the households in the home countries [36].

International remittances literature is crowded with studies 
contextualizing Bangladesh like $[6,15,37-41]$ and its relationship has been explored with numerous economic and household factors using macro-level country data. But unfortunately, its direct linkage with educational and healthcare expenditure of Bangladesh using micro-level data did not catch attention yet. Thus, issue of international remittances at household level using primary data from Bangladesh perspective is a virgin area. Henceforth, these research gaps make our study more constructive and justified.

\section{Data and Materials}

\subsection{Study Area and Data Collection}

In order to carry out the study, primary data are collected from Cumilla district of Bangladesh. The rationale for selecting this district as study area is that every year many people from this district migrate abroad searching for better livelihoods. The district consists of 16 police stations. Employing multi-stage random sampling technique, Devidwar, Daudkandi and Burichong police stations are selected randomly form those police stations. Then, two unions are selected randomly from each police station. In the next step, from each union three villages are selected randomly. Finally, from each village 11 remittance recipient and 11 non-recipient households are selected randomly following Abbas et al. [42]. Consequently, a total of 396 household heads are scheduled for interview and data are collected from January to March, 2019 with a well-structured questionnaire.

\subsection{Descriptive Statistics}

To analyze the socio-economic features of households in the study area, the study applies descriptive statistics like frequency distribution. Beyond analysis, the estimated result is presented in tabular form.

\subsection{Multiple Regression Analysis}

Remittance plays a vital role at household level in many ways. Thus, it requires seeking out the extent to what international remittances impacts on education and health in Bangladesh. To estimate the extent, household expenditure on education and healthcare purpose is considered as dependent variable. As the dependent variable is continuous, the study applies a multiple regression model estimated through OLS method which shows a cause and effect relationship between dependent variable and a set of explanatory variables following Abbas et al. [42], Raihan et al. [43] Banik and Kumar [44] and Kumar [45]. Equation 1 states the relationship as follows:

$$
E X P_{i}=f\left(P_{i}\right)
$$

Econometrically the equation 1 can be formed as:

$$
E X P_{i}=\delta P_{i}+\varepsilon_{i}
$$

where, $\mathrm{EXP}_{\mathrm{i}}$, dependent variable, is the monthly per capita expenditure on education and health and $\mathrm{P}_{\mathrm{i}}$ is a set of explanatory variables that affect the dependent variable. More specifically, on the basis of the equation (2), multiple regression models for education and health can be written as:

$$
\begin{gathered}
E X P_{e i}=\delta_{0}+\delta_{1} E D+\delta_{2} H S+\delta_{3} O C+\delta_{4} I L+\delta_{5} L S+\delta_{6} P I+\delta_{7} R E+\varepsilon_{i} \\
E X P_{h i}=\delta_{0}+\delta_{1} E D+\delta_{2} H S+\delta_{3} O C+\delta_{4} I L+\delta_{5} L S+\delta_{6} P I+\delta_{7} R E+\varepsilon_{i}
\end{gathered}
$$

where, $\mathrm{EXP}_{\mathrm{ei}}$ and $\mathrm{EXP}_{\mathrm{hi}}$ are monthly per capita expenditure on education and monthly per capita expenditure on health, respectively, $\delta_{0} \ldots \ldots \delta_{7}$ are parameters to be estimated and $\epsilon_{\mathrm{i}}$ is the stochastic disturbance term. The explanatory variables used in above model are explained in Table 1. All these variables have been considered in the regression model from literature review.

Table 1. Description of explanatory variables used in both regression models.

\begin{tabular}{lll}
\hline Name of Variables & Type & Measurement \\
\hline Education (ED) & Continuous & Schooling of household head (years) \\
Household size (HS) & Continuous & Total number of family members \\
Occupation (OC) & Dummy & 1 for non-agriculture, otherwise 0 \\
Income from livestock (IL) & Continuous & Yearly income from livestock of household (Tk.) \\
Land size (LS) & Continuous & Total amount of land (Bighas) \\
Per capita income (PI) & Continuous & Monthly per capita income of household (Tk.) \\
Remittance (RE) & Dummy & 1 if household receives remittances, otherwise 0 \\
\hline
\end{tabular}

\section{Results and Discussion}

\subsection{Education Related Features of Households}

This segment presents a comparative analysis on the education related features of the children of both remittance recipient and non-recipient households which may bring out the core scenario of education of two groups of households. The result has been analyzed through SPSS 23 and presented in tabular form in the following table. 
Table 2. Education Related Features of Households.

\begin{tabular}{|c|c|c|c|}
\hline \multirow{2}{*}{ Variables } & \multirow{2}{*}{ Indicators } & \multicolumn{2}{|l|}{$\%$ of households } \\
\hline & & Remittance recipient & Remittance non-recipient \\
\hline \multirow{3}{*}{ Types of school } & Government & 48 & 66 \\
\hline & Non-government & 37 & 30 \\
\hline & Private & 13 & 4 \\
\hline \multirow{3}{*}{ Medium of instruction of the study } & Bengali & 93 & 97 \\
\hline & English & 7 & 3 \\
\hline & Beside home & 45 & 69 \\
\hline \multirow[t]{2}{*}{ Distance of school from home } & $1.00 \mathrm{~km}$ to $2.00 \mathrm{~km}$ & 40 & 27 \\
\hline & $2.01 \mathrm{~km}$ and above & 15 & 4 \\
\hline \multirow{4}{*}{ Medium of transportation in going school } & On foot & 14 & 55 \\
\hline & By personal transport & 25 & 6 \\
\hline & By public transport & 53 & 35 \\
\hline & By school transport & 7 & 4 \\
\hline \multirow{2}{*}{ House tutor facilities } & Yes & 89 & 41 \\
\hline & No & 11 & 59 \\
\hline \multirow{2}{*}{ Providing of education accessories timely } & Yes & 87 & 17 \\
\hline & No & 13 & 83 \\
\hline \multirow{3}{*}{ Types of Tiffin } & No Tiffin & 17 & 59 \\
\hline & Home made & 61 & 36 \\
\hline & Restaurant made & 22 & 5 \\
\hline \multirow{4}{*}{ Level of education (passed last year) } & Primary & 60 & 45 \\
\hline & Secondary & 20 & 29 \\
\hline & Graduation & 17 & 19 \\
\hline & Higher studies & 3 & 7 \\
\hline
\end{tabular}

Source: Field survey, 2019

Table 2 reveals that most of the children study in government school. It is found that most of the children of both remittance recipient and non-recipient households study in government school because most of the schools in the rural areas of Bangladesh are government school where there is low tuition fee. In the study area, about 48 percent remittance recipient households' children study in government school whereas it is about 66 percent for remittance non-recipient households. The study also finds that the rate of studying children at private school is higher for remittance recipient households than that of non-recipient households. With the help of remittances, remittance recipient households become able to pay higher tuition fee at private school. Although most of the children of both types of households study in Bengali medium, the medium of instruction of the study in English is higher for remittance recipient households. As most of the government schools are situated beside home and familiar with low tuition fee, mostly remittance non-recipient households (45 percent) and non-recipient households (69 percent) send their children at government schools beside their home. The study also finds that most of the households use public transport to send their children to school and they also use private transport. Remittance recipient households (25 percent) use private transport more than that of nonrecipient households ( 6 percent). The study finds that there are enough facilities of house tutor for remittance recipient households (89 percent) whereas remittance non-recipient households do not provide much home tutor facilities as they have no enough money to spend for it. The table also shows that 87 percent remittance recipient households provide education accessories timely to the children while 83 percent remittance non-recipient cannot provide timely. In addition, the households who receive remittance mostly provide their children home made Tiffin than non-recipient households. The table also shows that most of the children of both types of households have passed primary level education. Interestingly, it is found that children of remittance nonrecipient households ( 7 percent) passed higher studies more than remittance recipient households (3 percent) as remittance recipient households prefers sending their children abroad for earning remittance to sending them for higher studies.

From the above analysis, it is found that although recipient families are becoming able to bear educational expenditure and other facilities for their children with the help of remittance, they are failing to make their children educated in higher studies as they are sending their children abroad for earning remittances. Contrarily, remittance non-recipient households are making their children educated in higher studies despite being their lower capabilities to provide higher educational expenditure and other facilities.

\subsection{Health Related Features of Households}

This segment presents a comparative analysis between remittance recipient and non-recipient households on health related features in the following table. 
Table 3. Health Related Features of Households.

\begin{tabular}{llll}
\hline \multirow{2}{*}{ Variables } & Indicators & \% of households & Remittance non-recipient \\
\cline { 3 - 4 } Consumption of nutritious food regularly & Yes & 73 & 57 \\
& No & 27 & 43 \\
Medium of water purification & No purification & 31 & 64 \\
& Boiled & 13 & 11 \\
& Filtered & 45 & 16 \\
Uses of sanitary latrine & Sodish and other & Yes & 9 \\
& No & 96 & 91 \\
Methods of having treatment in serious disease & 4 & 9 \\
& No treatment & Visiting Kabiraj & 18 \\
Checking up health regularly & Visiting specialized doctor & 13 & 27 \\
Household head's knowledge about reproductive & Yes & 84 & 55 \\
health & Yes & 57 & 23 \\
Maintaining family planning & No & 43 & 77 \\
& No & 61 & 27 \\
Delivery Attendance & No & 39 & 73 \\
& Home (without CHW*) & 89 & 87 \\
\hline
\end{tabular}

Note: ${ }^{*} \mathrm{CHW}=$ Community Health Worker

Source: Field survey, 2019

Table 3 reveals that most of the households consume nutritious food regularly. However, remittance recipient households (73 percent) consume nutritious food regularly more than the non-recipient households ( 57 percent). The table also reveals that majority of the remittance recipient households (45 percent) use filter to purify water whereas most of the remittance non-recipient households (63 percent) do not use any method to purify water. The study also finds that most of the households use sanitary latrine and the rate of using sanitary latrine is greater for remittance recipient households (96 percent) than non-recipient households (91 percent). The table also shows that although most of the households of both categories visit specialized doctor for having treatment at the time of facing serious diseases, certain number of households do not visit specialized doctor as well. The rate of not visiting specialized doctor (having no treatment) is higher for remittance non-recipient households (18 percent) than remittance recipient households ( 3 percent). It is also found that 57 percent remittance recipient households check up their health regularly while the rate is 23 percent for non-recipient households. The study also finds that 61 percent remittance recipient households' head have knowledge about reproductive health while the rate is about 27 for remittance non-recipients. Although both types of households maintain family planning, the rate of maintaining is higher for recipient households. The table also finds that most of the remittance recipient households ( 52 percent) use hospital facilities during delivery time whereas most of the non-recipient households use home delivery scheme considering community health worker (41 percent). From the above analysis, it is found that international remittances have notable influence on health care facilities of the recipient households.

\subsection{Ratio of Per Capita Expenditure on Education and Health to Total Per Capita Household Expenditure}

The ratio of per capita expenditure on education and health to total per capita household expenditure of remittance recipient and non-recipient households has been measured through SPSS 23 and presented in the following table.

Table 4. Ratio of per capita expenditure on education and health to total per capita household expenditure (Tk./year).

\begin{tabular}{|c|c|c|c|c|c|}
\hline \multirow{2}{*}{ Sectors } & \multicolumn{2}{|c|}{ Remittance recipient } & \multicolumn{2}{|c|}{ Remittance non-recipient } & \multirow{2}{*}{ Mean Difference (1-2) } \\
\hline & Mean (1) & $\%$ & Mean (2) & $\%$ & \\
\hline Education & 2398.82 & 3.74 & 3188.91 & 13.32 & -790.09 \\
\hline Health & 1991.34 & 3.11 & 727.96 & 3.04 & 1263.38 \\
\hline Others & 59698.66 & 93.15 & 20012.31 & 83.63 & 39686.35 \\
\hline Total & 64088.82 & 100 & 23929.18 & 100 & 40159.64 \\
\hline
\end{tabular}

Source: Field survey, 2019

From this above table, an interesting result has been found that the amount of annual per capita expenditure on education of remittance non-recipient households (Tk. 3188.91 ) is lower than that of remittance recipient 
households (Tk. 2398.82). While remittance recipient households expense about 3.74 percent of total per capita expenditure per year on education purpose, remittance nonrecipient households expense about 13.32 percent. The reason behind this difference is that remittance recipient households educate their children up to secondary or higher secondary level and send them abroad for earning more remittance. Contrarily, remittance non-recipient households have no many alternative options to earn and that is why they educate their children up to higher studies which incurs more expenditure on education. Besides education purpose, households expense on health purpose as well. The paper finds that remittance recipient households (Tk.1991.34) expense more on health care purpose than that of remittance non-recipient households (Tk. 727.96). Although both types of households spend money on health care purpose almost at the same rate, remittance recipient households ( 3.11 percent) expense more than that of remittance non-recipient households ( 3.04 percent). This result can be explained by the fact that remittance recipient households can be able to enjoy better health care facilities with the presence of remittance. From the above analysis it is found that international remittances have a notable influence on health care but not in education.

\subsection{Impact of Remittances on Education}

The linear regression model for measuring the extent to what international remittances impact on education is analyzed with STATA-13 and the result is presented in Table 5.

Table 5. Impact of Remittances on Education.

\begin{tabular}{lllll}
\hline Variables & Coefficient & Robust std. Err. & t-ratio & P>|t| \\
\hline Cons. & 76.01 & 214.51 & 0.35 & 1.16 \\
Education & 96.59 & 83.45 & -2.25 & 0.72 \\
Household size** & -154.29 & 68.55 & 1.22 & 0.25 \\
Occupation & 167.81 & 137.18 & 0.68 & 0.22 \\
Income from livestock & 0.0578 & 0.0849 & 4.14 & 0.49 \\
Land*** & 372.47 & 89.89 & 9.35 & 0.00 \\
Per capita income*** & 0.1892 & 0.0202 & -6.64 \\
Remittance*** & -1020.67 & 153.65 & 0.00 \\
\hline
\end{tabular}

$\mathrm{F}(7,388)=675.32 ;$ Prob $>\mathrm{F}=0.000 ; \mathrm{R}^{2}=0.97 ;$ Root $\mathrm{MSE}=685.68 ; \mathrm{DW}=1.97$

Note: $* * *, * *$ means $1 \%$ and $5 \%$ level of significance.

Source: Field survey, 2019

The table 5 shows that the value of $R^{2}$ is 0.97 indicates that explanatory variables of the model explain the dependent variable by 97 percent. Elsewhere, the F-statistic value is 675.32 with prob $>\mathrm{F}=0.000$ brings out that the model is completely good at fitted. The study has no any heteroscedasticity problem in the data that is clarified using robust standard error action. The study also exercises VIF to detect multicollinearity problem and explicitly reveals a negative result. The Durbin Watson test $(\mathrm{DW}=1.97)$ expresses that no autocorrelation problem exists in the model The study finds that household size, land, per capita income and remittance are significant variables although all variables fulfill the expected sign except remittance.

The coefficient of household size reveals that the per capita household expenditure on education per month may be decreased by Tk.154.29 if the household's family member is increased by one which is significant at 5 percent level of significance. The rational explanation may be that households with large number of family members have to spend huge amount of expenditure in different purposes like food and nonfood items, housing, health, investment purposes and so on. That is why per capita expenditure on education becomes low. Abbas et al. [42] have also found the same findings.

Similarly, the per capita household expenditure on education per month may be increased by Tk.372.47 if the household head holds an extra unit of land. This result is significant at 1 percent level of significance and can be interpreted by the fact that households with large size of land can produce crops, vegetables, fisheries, livestock and so on. This can build a strong basement for the household expenditure on education.

The study also finds that the per capita household expenditure on education per month will be increased by Tk.0.1892 if household's per capita income is increased by one unit which is significant at 1 percent significance level. The interpretation may be such that households with higher per capita income can expense more on education. Abbas et al. [42] have also found the same findings.

The coefficient of remittance reveals that the per capita household expenditure on education per month may be decreased by Tk.1020.67 if the households receive remittance which is significant at 1 percent level of significance. The rational explanation may be that remittance recipient households receive remittance and educate their children up to secondary or higher secondary level and send abroad for earning more remittances. For this reason, per capita expenditure on education of remittance recipient households is too lower than that of remittance non-recipient households. The result is in line with McKenzie and Rapoport [27] Antman [28], Lee and Park [29] and Mansoor and Quillin [30]. At the same time, the result violates the result of Abbas et al. [42] and Raihan et al. [43].

\subsection{Impact of Remittances on Health}

Besides measuring the impact of international remittances on education, the study also measures the extent to what 
international remittances impact on health using a linear regression model estimated by OLS method. The ressult is analyzed with STATA-13 and the estimated result is presented in Table 6 .

Table 6. Impact of Remittances on Health.

\begin{tabular}{lllll}
\hline Variables & Coefficient & Robust std. Err. & t-ratio & P>|t| \\
\hline Cons. & -1082.81 & 875.68 & -1.24 & -4.79 \\
Education*** & -1507.76 & 314.78 & 1.07 & 0.00 \\
Household size & 304.19 & 284.71 & 4.33 & 0.29 \\
Occupation*** & 2297.97 & 530.91 & -6.51 & 0.00 \\
Income from livestock*** & -2.36 & 0.34 & 5.88 & 0.00 \\
Land*** & 2687.65 & 456.82 & 4.90 & 0.00 \\
Per capita income*** & 0.4828 & 0.099 & 0.00 \\
Remittance*** & 4817.39 & 776.41 & 0.00 \\
\hline
\end{tabular}

$\mathrm{F}(7,388)=20.07 ;$ Prob $>\mathrm{F}=0.000 ; \mathrm{R}^{2}=0.86 ;$ Root $\mathrm{MSE}=2661.2 ; \mathrm{DW}=1.99$

Note: $* * *$ means $1 \%$ level of significance.

Source: Field survey, 2019

The Table 6 shows that the value of $R^{2}$ is 0.86 indicates that explanatory variables of the model explain the dependent variable by 86 percent. Elsewhere, the F-statistic value is 20.07 with prob $>\mathrm{F}=0.000$ brings out that the model is completely good at fitted. The study has no any heteroscedasticity problem in the data that is clarified using robust standard error action. The study also exercises VIF to detect multicollinearity problem and explicitly reveals a negative result. The Durbin Watson test $(\mathrm{DW}=1.99)$ expresses that no autocorrelation problem exists in the model. The study finds that education, occupation, income from livestock, land, per capita income and remittance are significant variables.

The estimated coefficient of education is -1507.76 exhibits that the per capita household expenditure on health per month may be decreased by Tk.0.0060 if the level of education of household head is increased by one year. This is significant at 1 percent level of significance. The dynamic explanation may be that the more the household head being educated the more he or she will be conscious of basic hygiene and health. That is why they do not get ill and need not to take health care facilities. The result is in line with Abbas et al. [42].

The per capita household expenditure on health per month may be increased by Tk.2297.97 if the occupation of household head is non-agricultural which is significant at 1 percent level of significance. The interpretation may be that household heads earn more income when they are involved in non-agricultural activities like services, business and so on. This paves the way to expense more on health care.

Similarly, the per capita household expenditure on health per month may be increased by Tk.2687.65 if the household head holds an extra unit of land. This result is significant at 1 percent level of significance and can be interpreted by the fact that households with large size of land can produce crops, vegetables, fisheries, livestock and so on. This can build a strong basement for the household expenditure on health.

The per capita household expenditure on health per month may be decreased by Tk.2.36 if the households' income from livestock is added by one unit. This result is significant at 1 percent level of significance and can be interpreted by the fact that households which have enough livestock have enough facilities of nutrition which makes them physically fit and lowers the health care cost. Abbas et al. [42] have also found the same findings.

The study also finds that the per capita household expenditure on health per month may be increased by Tk.0.4828 if household's per capita income is increased by one unit which is significant at 1 percent significance level. The interpretation may such that households with higher per capita income can expense more on health care. Abbas et al. [42] have also found the same findings.

The coefficient of remittance reveals that the per capita household expenditure on health per month may be increased by Tk.4817.39 if the household receives remittance which is significant at 1 percent level of significance. The rational explanation may be that remittance recipient households can easily meet their health care expenditure with the blessings of remittance. The result is in line with Amuedo-Dorantes and Pozo [12], Adams [31], Olowa and Awoyemi [32], Ponce et al [33], Démurger and Wang [34], Thapa and Acharya [35] and Abbas et al. [42].

\section{Conclusion and Policy Recommendations}

This paper focuses on two separate questions. Such as: 1) do international remittances affect education in Bangladesh? and 2) do international remittances affect health in Bangladesh? To investigate these questions, this study uses primary data collected from remittance recipient and nonrecipient households and employs several methods. Finally, this paper finds some interesting results. The results are interesting in many aspects as follows:

First, the study finds that international remittances have negative and significant impact on education of remittance recipient households. Empirically, this paper reveals that if a household receives international remittances, the per capita expenditure on education of that household is decreased by Tk.1020.67 which interprets that remittance have no role in improving education status of the recipient households. Second, 
the study finds a positive and significant relationship between remittances and health. The study empirically finds that if a household receives international remittances, the per capita expenditure on health care of that household is increased by Tk.4817.39 which reveals that international remittances have positive and significant role in improving health status.

On the basis of the findings of this study, government and authorized non-government organizations are suggested to take policies to aware remittance recipient households about utilizing remittances on health care purpose. Although remittance are found as a negative factor affecting education, moreover, the study suggests remittance recipient households to make their children educated up to higher studies so that they can be turned into skilled human resources and contribute to the country's sustainable development. As the study has been carried out within very short time and budget, the study suggests to carry out further study on it.

\section{References}

[1] UNDESA (2017). International Migration Report 2017. doi: ST/ESA/SER.A/404.

[2] International Organization for Migration (IOM). (2017). World Migration Report 2018. Retrieved from: https://publications.iom.int/system/files/pdf/wmr_2018_en.pdf.

[3] Bayes, A., Hossain, M., and Rahman, A. M. (2015, November 17). Remittances and poverty alleviation. Retrieved from http://dspace.bracu.ac.bd:8080/xmlui/bitstream/handle/10361/ 4744/Remittances and povertyalleviation17_nov_2015. pdf? sequence $=1$.

[4] OECD. (2017). International Migration Outlook 2017. doi: 10.1787/migr_outlook-2017-en.

[5] BMET. (2018). Overseas Employment and Remittances from 1976-2018. Retrieved from: http://www.bmet.org.bd/BMET/ stattisticalDataAction.

[6] Kumar, R. R., Stauvermann, P. J., Kumar, N. N., and Shahzad, S. J. H. (2018a). Revisiting the threshold effect of remittances on total factor productivity growth in South Asia: a study of Bangladesh and India. Applied Economics, 50 (26), 28602877. doi: 10.1080/00036846.2017.1412074.

[7] Calero, C., Bedi, A. S., and Sparrow, R. (2009). Remittances, liquidity constraints and human capital investments in Ecuador. World Development, 37 (6), 1143-1154. doi: 10.1016/j.worlddev.2008.10.006.

[8] Nguyen, C. V., and Nguyen, H. Q. (2015). Do internal and international remittances matter to health, education and labor of children and adolescents? The case of Vietnam. Children and Youth Services Review, 58, 28-34. doi: 10.1016/j.childyouth.2015.09.002.

[9] Chaaban, J., and Mansour, W. (2012). The impact of remittances on education in Jordan, Syria and Lebanon. Economic Research Forum Working Paper No. 684, 69-98. Retrieved from: http://erf.org.eg/publications/.

[10] Phuyal, R. K., Dhakal, R. C., and Koirala, A. (2016). Remittances and household expenditure patterns of selected families in Kathmandu remittances and household expenditure patterns of selected families in Kathmandu valley. Regional Development Studied, 48 (2), 67-87. Retrieved from: http://www.uonbi.ac.ke/node/878.

[11] Edwards, A. C., and Ureta, M. (2003). International migration, remittances, and schooling: Evidence from El Salvador. Journal of Development Economics, 72 (2), 429-461. doi: 10.1016/S0304-3878(03)00115-9.

[12] Amuedo-Dorantes, C., and Pozo, S. (2011). New evidence on the role of remittances on healthcare expenditures by Mexican households. Review of Economics of the Household, 9 (1), 6198. doi: 10.1007/s11150-009-9080-7.

[13] Valero-Gil, J. (2009). Remittances and the household's expenditures on health. Journal of Business Strategies, 29 (1): 119-140. Retrieved from: http://eprints.uanl.mx/id/eprint/7523.

[14] Adams, R. H. J., and Cuecuecha, C. (2010). The economic impact of international remittances on poverty and household consumption and investment in Indonesia. World Bank Policy Research Working Paper (No. 5433). doi: 10.1596/18139450-5433.

[15] Kumar, B., Hossain, M. E. and Osmani, M. A. G. (2018b). Utilization international remittances in Bangladesh. Remittances Review, 3 (1), 5-18. Available at: https://journal.tplondon.com/index.php/rem/article/view/986.

[16] Amuedo-dorantes, C., Bansak, C., and Pozo, S. (2005). On the Remitting Patterns of Immigrants: Evidence from Mexican Survey Data. Federal Reserve Bank of Atlanta Economic Review, 90 (1), 37-58. Retreived from: https://www.frbatlanta.org/

[17] Adams, R. H., and Page, J. (2005). Do international migration and remittances reduce poverty in developing countries? World Development, 33 (10), 1645-1669. doi: 10.1016/j.worlddev.2005.05.004.

[18] Bansak, C., Chezum, B., and Giri, A. (2015). Remittances, school quality, and household education expenditures in Nepal. IZA Journal of Migration, 4 (1), 16. doi: 10.1186/s40176-0150041-z.

[19] Dhungana, A. R., and Pandit, D. (2014). Socio-economic impact of remittance on households in Lekhnath municipality, Kaski, Nepal. Economic Literature, 12, 39-49. doi: 10.3126/el.v12i0.14886.

[20] Tabuga, A. D. (2007). International remittances and household expenditures: the Philippine Case. Discussion Paper Series No. 2007-18. Retrieved from: https://dirp3.pids.gov.ph/ris/dps/ pidsdps0718.pdf.

[21] Adams, R. H., and Cuecuecha, A. (2013). The impact of remittances on investment and poverty in Ghana. World Development, 50, 24-40. doi: 10.1016/j.worlddev.2013.04.009.

[22] Ratha, D. (2013). The impact of remittances on economic growth and poverty reduction. Policy Brief, 8, 1-13. doi: $10.1177 / 056943451005500210$.

[23] Kanaiaupuni, S. M., and Donato, K. M. (1999). Migradollars and mortality: the effects of migration on infant survival in Mexico. Demography, 36 (3), 339-353. doi: 10.2307/2648057.

[24] Acosta, P. (2006). Labor supply, school attendance, and remittances from international migration: the case of El Salvador. World Bank Policy Research Working Paper (No. 3903). doi: 10.1596/1813-9450-3903. 
[25] Acosta, P., Calderón, C., Fajnzylber, P., and Lopez, H. (2008). What is the impact of international remittances on poverty and inequality in Latin America? World Development, 36 (1), 89114. doi: 10.1016/j.worlddev.2007.02.016.

[26] Cordova, E. P. (2005). Globalization, migration and development: the role of mexican migrant remittances. Economia, 6 (1), 217-256. Retrieved from: https://www.jstor.org/stable/20065489.

[27] McKenzie, D., and Rapoport, H. (2011). Can migration reduce educational attainment? Evidence from Mexico. Journal of Population Economics, 24 (4), 1331-1358. doi: 10.1007/s00148-010-0316-x.

[28] Antman, F. M. (2011). The intergenerational effects of paternal migration on schooling and work: What can we learn from children's time allocations? Journal of Development $\begin{array}{llll}\text { Economics, } & 92 & \text { (2), 200-208. doi: }\end{array}$ 10.1016/j.jdeveco.2010.11.002.

[29] Lee, L., and Park, A. (2010). Parental migration and child development in china (working paper). Gansu Survey of Children and Families. Retrieved from https://repository. upenn.edu/cgi/viewcontent.cgi?article $=1023$ andcontext=gansu papers.

[30] Mansoor, A., and Quillin, B. (2006). Migration and remittances: Eastern Europe and the Former Soviet Union. Retrieved from http://siteresources.worldbank. org/INTECA/Resources/2578961167856389505/Migration F ullReport.pdf.

[31] Adams, R. H. (2011). Evaluating the economic impact of international remittances on developing countries using household surveys: A literature review. Journal of Development Studies, 47 (6), 809-828. doi: 10.1080/00220388.2011.563299.

[32] Olowa, O. W., and Awoyemi, T. T. (2009). Remittances and household expenditure in rural Nigeria. Journal of Rural Economics and Development, 20 (1), 30-43. Retrieved from https://ideas.repec.org/s/ags/ngjred.html.

[33] Ponce, J., Olivié, I., and Onofa, M. (2011). The role of international remittances in health outcomes in Ecuador: Prevention and response to shocks. International Migration Review, $45 \quad$ (3), 727-745. doi: 10.1111/j.17477379.2011.00864.x.

[34] Démurger, S., and Wang, X. (2016). Remittances and expenditure patterns of the left behinds in rural China. China Economic Review, 37, 177-190. doi: 10.1016/j.chieco.2015.12.002.
[35] Thapa, S., and Acharya, S. (2017). Remittances and household expenditure in nepal: evidence from cross-section data. Economies, 5 (2), 16. doi: 10.3390/economies5020016.

[36] Amuedo-Dorantes, C., Sainz, T., and Pozo, S. (2007). Remittances and healthcare expenditure patterns of populations in origin communities: evidence from Mexico. Integration and Trade, 25, 1-23. Retrieved from https://publications.iadb.org/handle/11319/2620.

[37] Hassan, G., and Shakur, S. (2017). Nonlinear effects of remittances on per capita gdp growth in Bangladesh. Economies, 5 (3), 25. doi: 10.3390/economies5030025.

[38] Hatemi-J, A., and Uddin, G. S. (2014). On the causal nexus of remittances and poverty reduction in Bangladesh. Applied $\begin{array}{lllll}\text { Economics, } 46 & 46 \text { (4), 374-382. }\end{array}$ 10.1080/00036846.2013.844331.

[39] Khan, Z. S., and Islam, S. (2013). The Effects of remittances on inflation: evidence from Bangladesh. Journal of Economics and Business Research, 19 (2), 198-208. Retrieved from: http://www.uav.ro/jour/index.php/jebr/article/view/94.

[40] Regmi, M., and Paudel, K. P. (2016). Impact of remittance on food security in Bangladesh. Frontiers of Economics and Globalization, 16, 145-158. doi: 10.1108/S1574871520150000016006 .

[41] Wadood, S. N., and Hossain, M. A. (2017). Microeconomic impact of remittances on household welfare: Evidences from Bangladesh. Business and Economic Horizons, 13 (1), 10-29. doi: 10.15208/beh.2017.02.

[42] Abbas, K., Sabir, H. M., Shehzadi, A. and Abbas, Q. (2014). Impact of workers' remittances on household welfare in District Jhang (a case study of Tehsil 18 Hazari). Journal of Finance and Economics, 2 (4): 131-135. doi: 10.12691/jfe-24-5.

[43] Raihan, S., Khondker, B. H., Sugiyarto, G. and Jha, S. (2009). Remittances and household welfare: a case study of Bangladesh. ADB working paper. No. 189. Retrieved from: https://www.adb.org/sites/default/files/publication/28402/econ omics-wp189.pdf.

[44] Banik, P. and Kumar, B. (2019). Impact of information literacy skill on students' academic performance in Bangladesh. International Journal of European Studies, 3 (1), 27-33. doi: 10.11648/j.ijes.20190301.15.

[45] Kumar, B. (2019). The impact of international remittances on poverty alleviation in Bangladesh. Remittances Review, 4 (1), 67-86. Retrieved from: https://journals.tplondon.com/ index.php/rem/article/ view/665. 